\title{
PENGARUH PENAMBAHAN PATI TALAS LOKAL (Colocasia esculenta) SEBAGAI STABILIZER TERHADAP TOTAL PADATAN TERLARUT DAN KADAR AIR YOGURT PADA SUHU PASTEURISASI $90^{\circ} \mathrm{C}$
}

\author{
Aju Tjatur Nugroho Krisnaningsih ${ }^{1}$,Dimas Partidina Puriastuti Hadiani ${ }^{1}$, Maria Meryana Fila ${ }^{1}$ \\ ${ }^{1}$ Fakultas peternakan, Universitas Kanjuruhan Malang \\ Email: ajutjatur@unikama.ac.id
}

\begin{abstract}
ABSTRAK
Penelitian ini dilakukan di Laboratorium Terpadu Fakultas Peternakan, Universitas Kanjuruhan Malang dan Laboratorium Teknologi Pangan Universitas Brawijaya Malang, pada tanggal 30 Oktober sampai tanggal 31 November 2016. Tujuan dari penelitian ini untuk mengetahui pengaruh penambahan pati talas (Colocasia esculenta) terhadap total padatan terlarut dan kadar air yogurt pada suhu pasteurisasi $90^{\circ} \mathrm{C}$. Materi yang digunakan dalam penelitian ini adalah susu sapi segar, susu skim $2 \%$, starter bakteri Lactobacillus bulgaricus dan Streptococcus thermophillus $2 \%$, dan pati talas. Metode yang digunakan adalah percobaan Laboratorium dengan menggunakan Rancangan Acak Lengkap (RAL) yang terdiri dari 4 perlakuan yaitu penambahan pati talas $\mathrm{P} 0=0 \%, \mathrm{P} 1=0,5 \%, \mathrm{P} 2=1 \%, \mathrm{P} 3=1,5 \%$, masing-masing perlakuan diulang sebanyak 3 kali. Data yang diperoleh dianalisis dengan analisis ragam, apabila terdapat perbedaan maka dilanjutkan dengan uji Beda Nyata Terkecil (BNT). Variabel yang diamati meliputi total padatan terlarut dan kadar air yogurt. Hasil penelitian menunjukkan bahwa penambahan level pati talas (Colocasia esculenta) memberikan perbedaan yang sangat nyata $(\mathrm{P}<0,01)$ terhadap total padatan terlarut dan kadar air yogurt. Nilai total padatan terlarut yogurttertinggi pada penambahan pati talas 1,5\% sebesar 21,96\% kemudian berturut-turut level pati 1\%, 0,5\%, 0\% sebesar19,69\%, 18,33\% dan $17,35 \%$. Nilai kadar air yogurt pada penambahan pati talas $1,5 \%$ menghasilkan nilai terendah sebesar 77,36\% kemudian berturut-turut level pati $1 \%=80,50 \%, 0,5 \%=81,56 \%$ dan $0 \%=83,35 \%$. Berdasarkan hasil penelitian dapat disimpulkan bahwa penambahan pati talas sebagai stabilizer sebesar $1,5 \%$ menghasilkan kualitas yogurt yang optimal ditinjau dari total padatan terlarut dan kadar air yogurt pada suhu pasteurisasi $90^{\circ} \mathrm{C}$. Disarankan adanya penelitian lanjutan untuk mengetahui kualitas yogurt dengan penambahan pati talas diatas $1,5 \%$.
\end{abstract}

keywords: yogurt, pati, pasteurisasi, total padatan, kadar air

\section{Pendahuluan}

Susu merupakan bahan makanan bernilai gizi tinggi, kandungan gizinya lengkapdengan sifat gizi yang mudah dicerna dan diserap oleh tubuh. Ditinjau dari komposisi kimianya, susu merupakan minuman bergizi tinggi karena mengandung hampir semua zat gizi yang diperlukan tubuh manusia sehingga baik untuk dikonsumsi (Taufik, 2009). Susu mudah mengalami kerusakan oleh mikroorganisme, sehingga perlu dilakukan pengolahan dan pengawetan, antara lain dengan fermentasi susu menjadi yogurt (Malaka, 2007). Yogurt mempunyai nilai gizi yang lebih tinggi daripada susu segar sebagai bahan dasar dalam pembuatan yogurt ( Susilorini, dan Sawitri, 2007) serta sesuai bagi penderita lactoce intolerance atau yang tidak toleran terhadap laktosa (Marman, 2006)

Susu merupakan bahan pangan yang mempunyai nilai gizi tinggi karena mempunyai kandungan nutrisi yang lengkap seperti laktosa, lemak, protein berbagai vitamin, dan mineral (Widodo, 2003). Susu sapi sebagai bahan dasar pembuatan yogurt memiliki komposisi nutrisi (untuk setiap $100 \mathrm{ml}$ ), antara lain: kalori, protein, lemak, 


\section{Jurnal Sains Peternakan}

Volume 7 No. 2, Desember 2019, pp:148-156

ISSN 2579-445

laktosa, kalsium, kasein, besi, mineral, vitamin A, vitamin D, dan vitamin B6. Kandungan vitamin B6, asam folat, dan vitamin B12 pada susu sapi lebih tinggi dibanding susu kambing (Maheswari, 2008). Produk hasil olahan susu yogurt merupakan hasil pemeraman fermentasi bakteri Lactobacillus bulgaricus dan Streptococcus thermophillus (Ace dan Supangkat, 2006). Hasil penelitian Krisnaningsih dan Efendi (2015) menyatakan penambahan berbagai level susu skim dan masa inkubasi pada bahan dasar yogurt menghasilkan perbedaan yang sangat nyata terhadap nilai $\mathrm{pH}$ pada suhu pasteurisasi $90^{\circ} \mathrm{C}$.

Lactobacillus bulgaricus yang digunakan sebagai starter yogurt adalah spesies homofermentatif, menghasilkan $2 \%$ berat asam laktat pervolume susu. Temperatur optimum $42^{\circ} \mathrm{C}$ dan tetap tumbuh serta hidup pada suhu $45^{\circ} \mathrm{C}$ atau lebih. Spesies bakteri asam laktat tidak menyukai lingkungan dengan kadar garam rendah. Streptococcus thermophillus adalah satu-satunya spesies yang digunakan secara luas sebagai starter beberapa keju termasuk mozzarella dan yogurt, bakteri asam laktat termasuk bakteri termofilik yaitu bakteri yang tumbuh optimal pada suhu diatas $45^{\circ} \mathrm{C}$. Tejasari (2005), menyatakan bahwa fermentasi adalah proses pengolahan susu yang melibatkan aktivitas satu atau beberapa mikroorganisme yang menguntungkan, sehingga dapat meningkatkan nilai guna dan nilai sosial ekonomi suatu bahan produk.

Stabilizer dalam yogurt adalah subtansi untuk memperlembut atau memperlunak tekstur, membuat struktur gel dan mencegah serta mengurangi sinergis (keluarnya cairan) pada yogurt sehingga yogurt dapat lebih tahan lama. Bahan penstabil yang sesuai untuk yogurt adalah bila bahan tersebut tidak mengeluarkan flavour lain, efektif pada $\mathrm{pH}$ rendah dan dapat terdispersi dengan baik. Peningkatan kualitas yogurt dapat dilakukan dengan stabilizer, salah satu alternatif stabilizer alami yaitu pati talas. Pati mempunyai peranan yang sangat diperlukan dalam pengembangan produk makanan sebagai bahan baku, tambahan pangan seperti pengental, stabilizer atau memperbaiki tekstur (Aina, Falade, Akingbala and Titus, 2012). Pati merupakan bagian dari karbohidrat sumber utama penghasil energi dari pangan yang dikonsumsi oleh manusia yang bersumber dari tanaman sereal, umbi-umbian. Penyusun utama pati yaitu amilosa dan amilopektin (Hustiany, 2006).Pati merupakan sumber padatan dengan molekul amilopektin yang tinggi dan berdaya serap air tinggi (Hartati dan Prana, 2003). Talas merupakan salah satu bahan pangan dengan kandungan karbohidrat tinggi (Najgebauer-Lejko et al., 2007) sehingga bahan pangan ini memiliki kontribusi dalam menjaga ketahanan pangan dalam negeri dan juga berpotensi sebagai barang ekspor yang dapat menghasilkan keuntungan (Revill, Jackson, Hafner, Yang. 2005). 
Penambahan total padatan pada proses pembuatan yogurt sangat diperlukan agar dapat meningkatkan kualitas yogurt. Total padatan yang dapat ditambahkan salah satunya adalah pati dari umbi talas. Umbi talas merupakan salah satu komoditas pertanian di Indonesia (Minantyorini dan Somantri, 2002). Kandungan nutrisi yang tinggi 23,7 mg seperti karbohidrat (pati), vitamin dan mineral (kalsium dan fosfor) ada pada umbi talas (Sefa, Dedeh and Agyir-Sackey, 2004). sehingga umbi talas memiliki potensi yang baik dalam menunjang program diversifikasi pangan yang berbasis pada tepung dan pati.

Kadar air susu sangat tinggi, yang berfungsi sebagai bahan pelarut bahan kering (Wahyudi, 2006). Air didalam susu sebagian besar dihasilkan dari air yang diminum ternak sapi. Daya ikat air yogurt merupakan salah satu interaksi antar molekul protein serta antara molekul protein dan molekul air, akan menjadi faktor penting menentukan sifat dan fungsi protein sebagai pembentuk gel serta kualitas yogurt.Achmad, Nurwantoro dan Mulyani (2012) menyatakan bahwa bahan padatan bisa terdiri dari karbohidrat (pati) dengan proporsi penambahan level yang berbeda, pati ubi jalar Cilembu berpengaruh sangat nyata terhadap total padatan dan kadar air yogurt.

Berdasarkan uraian diatas maka diperlukan penelitian terkait pengaruh penambahan pati talas (Colocasia esculenta) sebagai stabilizer terhadap total padatan dan kadar air yogurt.

\section{Materi Dan Metode}

Materi yang digunakan adalah:

a. Susu sapi

Penelitian ini menggunakan susu sapi sebagai bahan dasar dalam pembuatan yogurt yang berkualitas baik, kualitas susu sangat berpengaruh besar dalam menghasilkan yogurt yang baik. Susu sapi yang digunakan berasal dari peternakan Pak Guntur sebanyak 4 liter.

a. Susu Skim

Susu skim yang digunakan dalam penelitian ini yaitu susu skim sebanyak $2 \%$ yang di beli di toko Avia Jl.Basuki Rahmat, Malang. Susu skim ditambahkan dalam pembuatan yogurt yang berfungsi untuk meningkatkan nilai protein pada yogurt.

b. Starter

Starter yang digunakan dalam penelitian ini sebanyak $2 \%$ yang di beli di Laboratorium Teknologi Hasil Ternak Fakultas Peternakan Universitas Brawijaya 
Malang. Starter berfungsi untuk menghasilkan asam laktat, asetaldehid membantu mengawetkan susu sertamemberi aroma yogurt.

c. Pati talas

Penelitian ini menggunakan pati yang berasal dari umbi talas ( Colocasia esculenta). Pati yang dibutuhkan dalam penelitian ini sebanyak 45 gr yang dihasilkan dari $2 \mathrm{~kg}$ umbi talas menjadi 160 gr pati dengan kualitas baik dan tidak memiliki cacat fisik.

Metode penelitian yang digunakan adalah percobaan laboratorium, merupakan prosedur pembuatan pati talas dan yogurt sebagai berikut tertera pada Gambar 1 dan 2 . Adapun perlakuan dalam penelitian ini di bedakan menjadi empat perlakuan yaitu sebagai berikut:

$\mathrm{P} 0=$ susu pasteurisasi + susu skim $2 \%$ tanpa pati talas (kontrol)

$\mathrm{P} 1=$ susu pasteurisasi + susu skim $2 \%+$ pati talas $0,5 \%$

$\mathrm{P} 2=$ susu pasteurisasi + susu skim $2 \%+$ pati talas $1 \%$

P3 = susu pasteurisasi + susu skim $2 \%+$ pati talas $1,5 \%$

\section{Rancangan dan Analisa Data}

RancanganPenelitian ini menggunakan Rancangan Acak Lengkap (RAL yang terdiri dari 4 perlakuan dan 3 ulangan sehingga diperoleh 12 unit penelitia.

\section{Analisa Data}

Data yang diperoleh dianalisis dengan analisis ragam dan apabila perlakuan berpengaruh maka akan dilanjutkan dengan uji BNT.

\section{Variabel yang akan diamati}

Variabel yang akan diamati dalam penelitian ini adalah:

a.Total Padatan Terlarut Yogurt (\%Brix)

b.Kadar Air Yogurt (\%)

\section{Hasil Dan Pembahasan}

\section{Total Padatan Terlarut Yogurt}

Total padatan merupakan bagian padat dari susu, nilai nutrisi yang terkandung di dalamnya terdiri dari protein, lemak, karbohidrat, vitamin, mineral yang tidak larut dalam air dan sebagian kecil air. Hasil analisis ragam menunjukan bahwa penambahan level pati talas (Colocasia esculenta) memberikan perbedaan yang sangat nyata $(\mathrm{P}<0,01)$ terhadap total padatan yogurt. Rata-rata nilai total padatan yogurt tertera pada Tabel 1 dan Gambar 1. 


\section{Jurnal Sains Peternakan}

Volume 7 No. 2, Desember 2019, pp:148-156

ISSN 2579-445

Tabel 1. Rata-Rata Nilai Total Padatan Yogurt

\begin{tabular}{lr}
\hline Perlakuan & Total padatan (\%Brix) \\
\hline P0 & $17,35 \pm 0,010^{\mathrm{a}}$ \\
P1 & $18,33 \pm 0,015^{\mathrm{b}}$ \\
P2 & $19,69 \pm 0,021^{\mathrm{c}}$ \\
P3 & $21,96 \pm 0,010^{\mathrm{d}}$ \\
\hline
\end{tabular}

Keterangan: Notasi yang berbeda a-d pada kolom yang samamenunjukan pengaruh sangat nyata $(\mathrm{P}<0,01)$

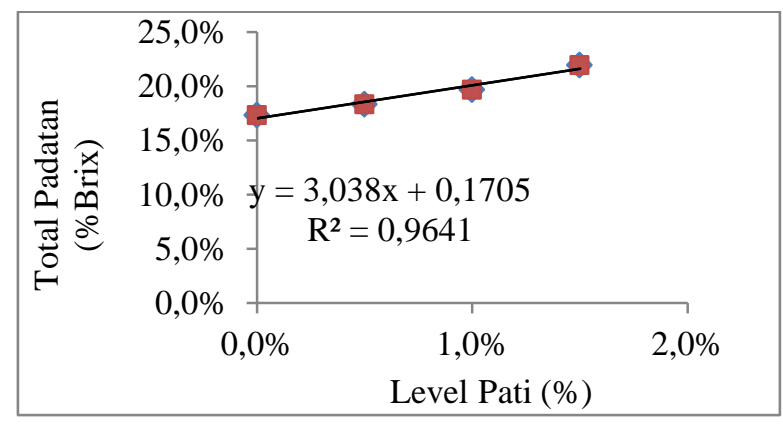

Gambar 1. Korelasi Total Padatan Yogurt

Perlakuan penambahan pati umbi talas (P3) 1,5\% memberikan perbedaan pengaruh yang sangat nyata $(\mathrm{P}<0,01)$ terhadap P0 $(0 \%)$, P1 $(0,5 \%)$ dan P2 $(1 \%)$. Nilai total padatan $1,5 \%$ (P3) memberikan nilai tertinggi pada penambahan pati sebesar 21,96\% berturut-turut $(\mathrm{P} 2) 1 \%=19,69 \%,(\mathrm{P} 1) 0,5 \%=18,33 \%$ dan $(\mathrm{P} 0) 0 \%=17,35 \%$ sedangkan menurut SNI total padatan menurut standar mutu yoghurt minimal 8,2 \%. Penggunaan pati umbi talas yang semakin banyak pada setiap perlakuan mulai dari P0 hingga P3 menyebabkan semakin meningkatnya nilai total padatan yang dihasilkan. Hal ini disebabkan karena pati umbi talas mengandung karbohidrat yang tinggi dimana karbohidrat merupakan salah satu penyusun padatan, selain itu molekul amilopektin pada pati sangat tinggi, sehingga yogurt yang dihasilkan memiliki tingkat kepadatan yang tinggi.

Total padatan merupakan bagian padat dari susu, nilai nutrisi yang terkandung di dalamnya terdiri dari protein, lemak, karbohidrat, vitamin, mineral yang tidak larut dalam air dan sebagian kecil air. Semakin tinggi konsentrasi penstabil, semakin tinggi total padatan terlarut. Total padatan terlarut meningkat karena air bebas diikat oleh bahan penstabil sehingga konsentrasi bahan yang larut meningkat. Semakin banyak partikel yang terikat oleh bahan penstabil maka total padatan yang terlarut juga akan semakin meningkat dan mengurangi endapan yang terbentuk. Dengan adanya bahan penstabil maka partikel-partikel yang tersuspensi akan terperangkap dalam sistem tersebutdan tidak mengedap oleh pengaruh gaya gravitasi. Peningkatan total padatan pada susu dapat dilakukan dengan penambahan umbi-umbian seperti pati talas yang dapat mengikat air. 


\section{Jurnal Sains Peternakan}

Volume 7 No. 2, Desember 2019, pp:148-156

ISSN 2579-445

Hasil penelitian Chairunnisa (2009), bahwa semakin tinggi total padatan maka semakin meningkat total bakteri asam laktat pada minuman fermentasi. Jika nutrisi dari bakteri asam laktat terpenuhi, maka akan membantu pertumbuhan dan perkembangan bakteri asam laktat. Lama fermentasi berpengaruh terhadap aktivitas mikroba pada suatu bahan pangan sehingga berpengaruh pada total bahan padat didalamnya (Krisnaningsih dan Efendi, 2015).

Achmad, Nurwantoro dan Mulyani (2012) menyatakan bahwa bahan padatan bisa terdiri dari karbohidrat (pati) dengan proporsi penambahan level yang berbeda, pati ubi jalar cilembu berpengaruh sangat nyata terhadap total padatan.

\section{Kadar Air Yogurt}

Pati merupakan salah satu komponen penyusun bahan pangan yang dapat berfungsi sebagai pengikat kadar air. Daya serap air tergantung pada jumlah pati dalam bahan pangan tersebut. Hasil analisis ragam menunjukan bahwa penambahan level pati talas (Colocasia esculenta) memberikan perbedaan yang sangat nyata $(\mathrm{P}<0,01)$ terhadap kadar air yogurt. Rata-rata nilai kadar air tertera pada Tabel 2 dan Gambar 2.

Tabel 2. Rata-Rata Kadar Air Yogurt

\begin{tabular}{lr}
\hline Perlakuan & Kadar Air (\%) \\
\hline P0 & $83,35 \pm 0,20^{\mathrm{d}}$ \\
P1 & $81,56 \pm 0,04^{\mathrm{c}}$ \\
P2 & $80,50 \pm 0,01^{\mathrm{b}}$ \\
P3 & $77,36 \pm 0,02^{\mathrm{a}}$ \\
\hline
\end{tabular}

Keterangan: Notasi yang berbeda a-d pada kolom yangsama menunjukan pengaruh sangat nyata $(\mathrm{P}<0,01)$

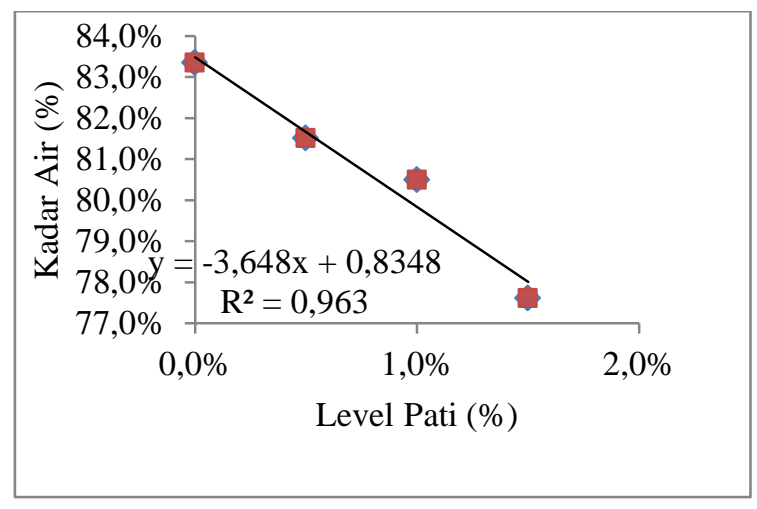

Gambar 2. Korelasi Kadar Air

Nilai kadar air yogurt menunjukan penurunan dengan kadar air semakin berkurang dengan penambahan stabilizer pati talas. Perlakuan penambahan pati umbi talas (P3) 1,5\% memberikan pengaruh yang sangat nyata $(\mathrm{P}<0,01)$ terhadap $\mathrm{P} 0(0 \%), \mathrm{P} 1$ $(0,5 \%)$ dan P2 (1\%). Nilai kadar air 1,5\% (P3) memberikan nilai terendah yaitu sebesar 


\section{Jurnal Sains Peternakan}

Volume 7 No. 2, Desember 2019, pp:148-156

ISSN 2579-445

$77,36 \%$ dan berturut-turut $(\mathrm{P} 2) 1 \%=80,50 \%$, $(\mathrm{P} 1) 0,5 \%=81,56 \%$ dan $(\mathrm{P} 0) 0 \%=$ $83,35 \%$. Hal tersebut disebabkan karena pati dapat meningkatkan total padatan bahan yang dikeringkan, sehingga jumlah air yang diuapkan semakin tinggi, akibatnya peningkatan konsentrasi pati akan menurunkan kadar air pada yogurt. Hal tersebut sesuai dengan pendapat Widowati, dan Djoko (2001), daya serap air menunjukan kemampuan bahan pangan dalam menyerap air. Daya serap air suatu bahan tergantung pada jumlah pati dalam yogurt dimana penurunan daya serap air disebabkan penurunan kadar pati dalam yogurt.

Menurut Winarno (2002), dalam bahan makanan, air merupakn komponen yang penting, karena air dapat mempengaruhi penampakkan, tekstur, serta cita rasa makanan. Di samping itu, kandungan air di dalam makanan ikut menentukan daya tahan bahan tersebut. Kandungan air yang tinggi akan mempercepat pertumbuhan mikrobia. Oleh karena itu, bahan pangan biasanya kadar airnya diturunkan sampai batas tertentu (Buckle et al., 2007). Menurut Tamime and Robinson (2007) menyatakan bahwa tujuan utama penambahan bahan penstabil pada yogurt adalah meningkatkan dan mempertahankan sifat karakteristik yogurt yang diinginkan seperti kekentalan, konsistensi,penambhan dan rasa yang khas. Peranan utama dari bahan penstabil terdiri atas dua tahap, yaitu pertama pengikatan air, dan yang kedua meningkatkan kekentalan yogurt.

Sawitri, Manab dan Palupi (2008) menyatakan bahwa penambahan bahan penstabil menyebabkan peningkatan sifat hidrofilik protein sehingga kemampuannya mengikat air meningkat.

\section{Kesimpulan}

Kesimpulan dari hasil penelitian ini yaitu penambahan pati talas $1,5 \%$ memberi kualitas yogurt yang optimal, ditinjau dari total padatan terlarut dan kadar air yogurt pada suhu pasteurisasi $90^{\circ} \mathrm{C}$.

\section{Daftar Rujukan}

Ace, I. S. dan S. Supangkat., 2006. Pengaruh Konsentrasi Starter terhadap Karakteristik Yoghurt. Jurnal Penyuluhan Pertanian [1:1].

Achmad, F., Nurwantoro., dan Mulyani, S. 2012. Daya Kembang, Total Padatan, Waktu Pelelehan, Dan Kesukaan Es Krim Fermentasi Menggunakan Starter Saccharomyces cereviceae. Animal Agriculture Journal. 1 (2) : 65-76.

Aina, A.J., K.O. Falade, J.O. Akingbala and P. Titus. 2012. Physicochemical Properties of Carribean Sweet Potato (Ipomoea batatas (L) Lam) Straches. Food Bioprocess Tech. 5: 576-583. 


\section{Jurnal Sains Peternakan}

Volume 7 No. 2, Desember 2019, pp:148-156

ISSN 2579-445

Buckle, K. A., R.A., Edwards, G. H. Fleet, dan M. Wootton. 2007. Ilmu pangan. Terjemahan Hari Purnomo dan Adiono. Universiitas Indonesia Press. Jakarta.

Chairunnisa H. 2009. Penambahan Susu Bubuk Full Cream Pada Pembuatan Produk Minuman Fermentasi Dari Bahan Baku Ekstrak Jagung Manis. Universitas Padjajaran: Jatinangor. Journal Teknologi dan Industri Pangan, Vol. XX No. 2 .Th 2009.

Hartati, N. S. dan T. K. Prana. 2003.Analisis Kadar Pati dan Serat KasarTepung Beberapa Kultivar Talas(Colocasia esculenta L. Shott) JurnalNatur Indonesia. 6 (1): 29-33.

Hustiany, R. 2006. Modifikasi Asilasi dan Suknilasi Pati Tapioka sebagai bahan Enkapsulasi Komponen Flavor Disertasi. Institut Pertanian Bogor.

Krisnaningsih, A.T.N dan A, Efendi. pengaruh penggunaan level susu skim dan masa inkubasi pada suhu ruang terhadap $\mathrm{pH}$ dan mutu organoleptik yogurt stirred. 2015. Jurnal Alam Hijau, Volume VI, No. 2, Februari 2015. Hal 54-63, ISSN 2086-6844.

Maheswari, R. 2008. Perbandingan Kandungan Nutrisi ASI, Susu Sapi dan Susu Kambing. Teknologi Hasil Ternak. Bogor: Fakultas Peternakan IPB.

Malaka, R. 2007. Ilmu dan Teknologi Pengolahan Susu. Yayasan Citra Emulsi, Makassar.

Minantyorini dan I.H. Somantri. 2002. Panduan Karakterisasi Dan Evaluasi Plasma nutfah Talas. Komisi Nasional Plasma Nutfah. 83 hlm.

Marman. 2006. Proses Pembuatan dan Analisis Mutu Yoghurt. Buletin Teknik Pertanian Vol. 11 No. 1

Najgebauer-Lejko, D., M. Sady, T. Grega, B. Faber, J. Agric. Domagala, and B.Machaczka. 2007. Effect of Addition of Starches of Different Botanical Origin On The Texture and Rheological Properties of Set-Style Yoghurts. Journal of Biotechnology in Animal Husbandry 23 (5-6), p 95-102.

Revill, P.A., Jackson, G.V.H., Hafner, G.J., Yang, I., Maino, M.K., Dowling, M.L., Devitt, L.C., Dale, J.L. and Harding, R.M. 2005. Incidence and distribution of viruses of taro ( Colocasia esculenta) in Pacific Island countries. Australasian Plant Pathology, 34 , 327-331.

Sawitri, E. M., Manab, A., Palupi, L. W. Theresia. 2008. Jurnal Ilmu dan Teknologi Hasil Ternak.

Sefa. S-Dedeh and E. K. Agyir-Sackey, 2004. Chemical composition and effect of processing on oxalate content of taro corms. Department of Nutrition \& Food Science, University of Ghana.

Susilorini, T. E. Dan M. E. Sawitri. 2007. Produk Olahan Susu. Penebar Swadaya, Jakarta.

Tejasari, 2005. Nilai Gizi Pangan, Graha Ilmu, Yogyakarta. 


\section{Jurnal Sains Peternakan}

Volume 7 No. 2, Desember 2019, pp:148-156

ISSN 2579-445

Tamime, A. Y dan R. K. Robinson. 2007. Yoghurt Science and Technology. Pergamon Press, New York.

Taufik, H. 2009. Mengenal Pembuatan dan Manfaat Yoghurt. Jakarta: Sinar Cemerlang Abadi.

Widodo, 2003. Bioteknologi Industri Susu. Lacticia Press, Yogyakarta.

Widowati, S. dan Djoko S. Damardjati. 2001. Menggali Sumberdaya Pangan Lokal dan Peran Teknologi Pangan Dalam Rangka Ketahanan Pangan Nasional. Majalah Pangan No. 36/X/Januari 2001. Puslitbang Bulog. Jakarta. Hal. 3-11.

Wahyudi, M. 2006. Proses Pembuatan dan Analisis Mutu Yoghurt. Buletin Teknik Pertanian, Vol 11. No 1. Balai Besar Penelitian dan Pengembangan Pasca Panen Pertanian. Bogor.

Winarno, F. G., 2002. Kimia Pangan dan Gizi. Gramedia. Jakarta. 